\title{
Mortgage Innovation, Mortgage Choice, and Housing Decisions
}

\author{
Matthew S. Chambers, Carlos Garriga, and Don Schlagenhauf
}

\begin{abstract}
This paper examines some of the more recent mortgage products now available to borrowers. The authors describe how these products differ across important characteristics, such as the down payment requirement, repayment structure, and amortization schedule. The paper also presents a model with the potential to analyze the implications for various mortgage contracts for individual households, as well as to address many current housing market issues. In this paper, the authors use the model to examine the implications of alternative mortgages for homeownership. The authors use the model to show that interest rate-adjustable mortgages and combo loans can help explain the rise—and fall—in homeownership since 1994. (JEL E2, E6)
\end{abstract}

Federal Reserve Bank of St. Louis Review, November/December 2008, 90(6), 585-608.

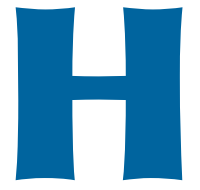

ousing is a big-ticket item in the U.S. economy. At the macro level, residential housing investment accounts for 20 to 25 percent of gross private investment. In the aggregate, this financing is about 8 trillion dollars and uses a sizable fraction of the financial resources of the economy. The importance of housing at the individual household level is more evident because the purchase of a house is the largest single consumer transaction and nearly always requires mortgage financing. This decision affects the overall expenditure patterns and asset allocation decisions of the household.

In recent years, interest in the role of housing in the U.S. economy has increased, influenced mainly by two events. During the economic downturn in 2000, the housing sector seemed to mitigate the slowdown in many other sectors of the economy as residential investment remained at high levels. More recently, the large number of foreclosures has again focused attention on the importance of housing. Fears have increased that mortgage market problems will have long-lasting effects on the credit market and thus continue to create a drag on the economy.

Events illustrating the important role of housing in the economy are not limited to those of the past decade. Housing foreclosures soared during the Great Depression as a result of two factors. The mortgage system was very restrictive: Homeowners were required to make down payments that averaged around 35 percent for loans lasting only five to ten years. At the end of the loan period, mortgage holders had to either pay off the loan or find new financing. The 1929 stock market collapse resulted in numerous bank failures. Mortgage issuance fell drastically, and homeowners were dragged into foreclosure. Faced with these problems, the government developed new housing policies as part of the New Deal legislation. The Home Owners' Loan Corporation (HOLC) and the Federal Housing Administration (FHA)

Matthew S. Chambers is an assistant professor of economics at Towson University. Carlos Garriga is an economist at the Federal Reserve Bank of St. Louis. Don Schlagenhauf is a professor of economics at Florida State University. The authors are grateful for the financial support of the National Science Foundation (grant No. SEP-0649374). Carlos Garriga also acknowledges support from the Spanish Ministry of Science and Technology (grant No. SEJ2006-02879). Michelle T. Armesto provided research assistance.

(C) 2008, The Federal Reserve Bank of St. Louis. The views expressed in this article are those of the author(s) and do not necessarily reflect the views of the Federal Reserve System, the Board of Governors, or the regional Federal Reserve Banks. Articles may be reprinted, reproduced, published, distributed, displayed, and transmitted in their entirety if copyright notice, author name(s), and full citation are included. Abstracts, synopses, and other derivative works may be made only with prior written permission of the Federal Reserve Bank of St. Louis. 
were created along with a publicly supported noncommercial housing sector. The HOLC was designed to help distressed homeowners avert foreclosure by buying mortgages near or in foreclosure and replacing them with new mortgages with much longer durations. The HOLC financed these purchases by borrowing from the capital market and the U.S. Treasury. The FHA introduced new types of subsidized mortgage contracts by altering forms and terms, as well as mortgage insurance. In addition, Congress created Federal Home Loan Banks in 1932 and the Federal Home Loan Mortgage Corporation, commonly known as Fannie Mae, in 1938. The latter organization was allowed to purchase long-term mortgage loans from private banks and then bundle and securitize these loans as mortgage-backed securities. ${ }^{1}$ These changes had an important impact on the economy: The stock of housing units increased 20 percent during the 1940s, and the homeownership rate increased approximately 20 percentage points from 1945 to 1965.

The need for increased understanding of housing markets, housing finance, and their linkage to the economy-the objective of this papershould be obvious. We begin by examining the structure of a variety of mortgage contracts. Given the array of available mortgage products, mortgage choice can be a complex problem for potential home buyers. Buyers must consider many dimensions, such as the down payment, maturity of the contract, repayment structure, the ability to refinance the mortgage, and the impact of changes in interest rates and housing prices. We present examples to clarify key features of prominent mortgage contracts. The best mortgage for one household need not be the best mortgage for another. In fact, a model is needed to understand the mortgage decisionmaking process and what the aggregate implications are for the economy. This model must explicitly recognize the differences among households in age, income, and

1 This increased the flow of resources available in areas in which savings were relatively scarce. The intent was to increase the opportunities for low-income families in the housing market. Because of the implicit backing of the government, the riskiness of these assets was perceived to be similar to the risk of U.S. Treasury securities. wealth. In addition, these decisions must reflect the complexities of the tax code that favor owneroccupied housing. Such a framework allows individual decisions to be aggregated so that the impact of mortgage decisions for the economy can be clearly identified.

The second part of this paper presents a model for understanding the impact of mortgage decisions on the economy. We use the model to show the role that adjustable-rate mortgages (ARMs) and combo loans have played since 1994 in the rapid riseand subsequent decline-in homeownership.

\section{MORTGAGE CONTRACTS}

A mortgage contract is a loan secured by real property. In real estate markets this debt instrument uses the structure (building) and land as collateral. In most countries mortgage lending is the primary mechanism to finance the acquisition of residential property. Mortgage loans typically are long-term contracts and require periodic payments that can cover interest and principal. Lenders provide the funds to finance the loans. Usually, such loans are sold to secondary market parties interested in receiving an income stream in the form of the borrower's payments.

The financial marketplace offers many types of mortgage loans, which are differentiated by three characteristics: the payment structure, the amortization schedule, and the term (duration) of the mortgage loan. The payment structure defines the amount and frequency of mortgage payments. The amortization schedule determines the amount of principal payments over the life of the mortgage. This schedule differs across types of mortgage loans and can be increasing, decreasing, or constant. Some contracts allow for no amortization of principal and full repayment of principal at a future, specified date. Other contracts allow negative amortization, usually in the initial years of the loan. ${ }^{2}$ The term or duration usually refers to the maximum length of time allotted to repay the

\footnotetext{
2 A mortgage contract with negative amortization means the monthly payment does not cover the interest on the outstanding balance. As a result, the principal owed actually increases. We illustrate such a contract later in the paper.
} 


\section{Table 1}

\section{Types of Primary Mortgage Contracts*}

\begin{tabular}{|c|c|c|c|c|c|c|}
\hline Type of contract & 1993* & 1995 & 1997 & 1999 & 2003 & 2005 \\
\hline Fixed-rate mortgage & 84.4 & 82.6 & 86.5 & 90.6 & 92.8 & 90.0 \\
\hline Adjustable-rate mortgage & 11.0 & 12.3 & 9.3 & 5.9 & 4.3 & 5.9 \\
\hline Adjustable-term mortgage & 0.2 & 0.0 & 0.8 & 0.8 & 0.3 & 0.4 \\
\hline Graduated-payment mortgage & 1.0 & 1.0 & 1.2 & 1.0 & 0.7 & 1.2 \\
\hline Balloon & 0.9 & 1.6 & 1.0 & 0.9 & 1.1 & 1.2 \\
\hline Other & 1.7 & 1.6 & 0.1 & 0.0 & 0.1 & 0.1 \\
\hline Combination of the above & 0.8 & 0.9 & 1.1 & 0.8 & 0.7 & 1.1 \\
\hline Sample size & 37,183 & 39,026 & 35,999 & 39,034 & 42,411 & 45,450 \\
\hline
\end{tabular}

NOTE: *Share of total contracts in percent.

SOURCE: U.S. Department of Commerce, American Housing Survey for various years.

mortgage loan. The most common mortgage contracts are for 15 and 30 years. The combination of these three factors allows a large variety of distinct mortgage products.

Mortgage contracts affect consumer decisions. For example, some contracts are more effective in allowing increased homeownership for younger households. What types of mortgage contracts are actually held in the United States? According to the 2001 Residential Finance Survey (U.S. Census Bureau, 2001), roughly 97 percent of housing units were purchased through mortgage loans, whereas only 1.6 percent were purchased with cash. Table 1 summarizes the types of mortgage contracts used in the United States. The fixed-rate (payment) mortgage loan is the dominant contract, and the popularity of an adjustable (or floating) rate mortgage is substantially smaller. In contrast, in the United Kingdom and Spain, where the homeownership rate is 71 and 80 percent, respectively, the adjustable (or floating) rate contract is the dominant contract. The popularity of the fixed-rate contract in the United States is largely a result of the policies of the FHA, Veterans Administration, and various government incentives to sell the loan in the secondary market. This is the role of enterprises such as Fannie Mae and the Federal Home Loan Mortgage Corporation (Freddie Mac), two government-sponsored enterprises (GSEs) that are among the largest firms that securitize mortgages. Mortgage securitization occurs when a mortgage contract is resold in the secondary market as a mortgage-backed security. In the early 1990s, substantial changes occurred in the structure of the mortgage market in the United States. According to data in the 2007 Mortgage Market Statistical Annual, the market share of nontraditional mortgage contracts has increased since 2000. Nontraditional or alternative mortgage products include interest-only loans, option ARMs, loans that couple extended amortization with balloon-payment requirements, and other contracts of alternative lending. For example, in 2004 these products accounted for 12.5 percent of origination loans. By 2006, this segment increased to 32.1 percent of loan originations. Given the declining share of conventional and conforming loans, the structure of mortgage contracts merits further consideration.

\section{General Structure of Mortgage Contracts}

Despite all their differences, mortgage loans are just special cases of a general representation. Some form of notation is needed to characterize this representation. Consider the expenditure associated with the purchase of a house of size $h$ and a unit price of $p$. We can consider $h$ as the number of square feet in the house and $p$ as the price per square foot. If buyers purchase a house 
with cash, the total expenditure is then denoted by $p h$. Most buyers do not have assets available that allow a check to be written for $p h$, and therefore they must acquire a loan to finance this large expenditure.

In general, a mortgage loan requires a down payment equal to $\chi$ percent of the value of the house. The amount $\chi p h$ represents the amount of equity in the house at the time of purchase, and $D_{0}=(1-\chi) p h$ represents the initial amount of the loan. In a particular period, denoted by $n$, the borrower faces a payment amount $m_{n}$ (i.e., monthly or yearly payment) that depends on the size of the original loan, $D_{0}$, the length of the mortgage, $N$, and the mortgage interest rate, $r^{m}$. This payment can be subdivided into an amortization (or principal) component, $A_{n}$, which is determined by the amortization schedule, and an interest component, $I_{n}$, which depends on the payment schedule. That is,

$$
m_{n}=A_{n}+I_{n}, \quad \forall n
$$

where the interest payments are calculated by $I_{n}=r^{m} D_{n} \cdot{ }^{3}$ An expression that determines how the remaining debt, $D_{n}$, changes over time can be written as

$$
D_{n+1}=D_{n}-A_{n}, \quad \forall n
$$

This formula shows that the level of outstanding debt at the start of period $n$ is reduced by the amount of any principal payment. A principal payment increases the level of equity in the home. If the amount of equity in a home at the start of period $n$ is defined as $H_{n}$, a payment of principal equal to $A_{n}$ increases equity in the house available in the next period to $H_{n+1}$. Formally,

$$
H_{n+1}=H_{n}+A_{n}, \quad \forall n,
$$

where $H_{0}=\chi p h$ denotes the home equity in the initial period. ${ }^{4}$

This representation of mortgage contracts is very general and summarizes many of the differ-

3 The calculation of the mortgage payment depends on the characteristics of the contract, but for all contracts the present value of the payments must be equal to the total amount borrowed,

$$
D_{0} \equiv \chi p h=\frac{m_{1}}{1+r}+\frac{m_{2}}{(1+r)^{2}}+\ldots+\frac{m_{N}}{(1+r)^{N}} .
$$

ent contracts available in the financial markets. For example, this formulation can accommodate a no-down-payment loan by setting $\chi=0$ so that the initial loan is equal to $D_{0}=p h$. Because this framework can be used to characterize differences in the amortization terms and payment schedules, we use it to describe the characteristics of some prominent types of mortgage loans.

\section{Mortgage Loans with Constant Payments}

In the United States, fixed-rate mortgages (FRMs) typically are considered the standard mortgage contract. This loan product is characterized by a constant mortgage payment over the term of the mortgage, $m \equiv m_{1}=\ldots=m_{N}$. This value, $m$, must be consistent with the condition that the present value of mortgage payments repays the initial loan. That is,

$$
D_{0} \equiv \chi p h=\frac{m}{1+r}+\ldots+\frac{m}{(1+r)^{N-1}}+\frac{m}{(1+r)^{N}} .
$$

If this equation is solved for $m$, we can write

$$
m=\lambda D_{0},
$$

where $\lambda=r^{m}\left[1-\left(1+r^{m}\right)^{-N}\right]^{-1}$. Because the mortgage payment is constant each period, and $m=$ $A_{t}+I_{t}$, the outstanding debt decreases over time $D_{0}>\ldots>D_{n}$. This means the fixed-payment contract front-loads interest rate payments,

$$
D_{n+1}=\left(1+r^{m}\right) D_{n}-m, \quad \forall n,
$$

and, thus, back-loads principal payments,

$$
A_{n}=m-r^{m} D_{n}
$$

The equity in the house increases each period by the mortgage payment net of the interest payment component:

$$
H_{n+1}=H_{n}+\left[m-r^{m} D_{n}\right], \quad \forall n .
$$

We now present some examples to illustrate key properties of the FRM contract.

\footnotetext{
4 It is important to state that for the sake of simplicity this framework assumes no changes in house prices. If house prices are allowed to change, then the equity equation would have to allow for capital gains and losses.
} 


\section{Table 2}

\section{Characteristics of a Fixed-Rate Mortgage at 6 Percent*}

\begin{tabular}{lcccc} 
Payment & Total payment (\$) & Interest (\$) & Principal (\$) & $\begin{array}{c}\text { Remaining } \\
\text { principal } \mathbf{( \$ )}\end{array}$ \\
\hline 1 & $1,178.74$ & 973.51 & 205.23 & $199,794.77$ \\
2 & $1,178.74$ & 972.51 & 206.23 & $199,588.54$ \\
120 & $1,178.74$ & 812.98 & 365.76 & $166,655.59$ \\
181 & $1,178.74$ & 686.89 & 491.85 & $140,625.26$ \\
219 & $1,178.74$ & 587.23 & 591.51 & $120,049.79$ \\
240 & $1,178.74$ & 523.73 & 655.01 & $106,940.84$ \\
251 & $1,178.74$ & 487.89 & 690.95 & $99,521.83$ \\
360 & $1,178.74$ & 5.71 & $1,173.03$ & 0.00 \\
Total & $424,346.40$ & $224,346.40$ & $200,000.00$ & - \\
NOTE: ${ }^{*}$ Based on 30-year maturity. & & & & \\
\hline
\end{tabular}

Example 1. Consider the purchase of a house with a total cost of $p h=\$ 250,000$ using a loan with a 20 percent down payment, $\chi=0.20$; an interest rate of 6 percent annually; and a 30-year maturity. This mortgage loan is for $\$ 200,000 .^{5}$ Table 2 illustrates the changes in interest and principal payments per month over the length of the mortgage contract.

The first two rows of Table 2 show the mortgage payment in the first and second months of the contract. The monthly payment on this mortgage is $\$ 1,178.74$. In the first period, $\$ 973.51$ of the monthly payment goes to interest rate payments. This means the principal payment is only $\$ 205.23 .{ }^{6}$ Now, let us consider the mortgage payment 10 years into the mortgage. Although the monthly payment does not change, the principal payment has increased to $\$ 365.76$ and the interest payment component has decreased to $\$ 812.98$. After 10 years, the homeowner has paid off only

\footnotetext{
5 Tables 2 through 9 apply to the following situation: house purchase price of $\$ 250,000$ with a down payment of 20 percent (total loan amount of $\$ 200,000$ ). Other parameters vary as noted in the individual examples.

6 This is the same example used in McDonald and Thornton (2008). The numbers presented here are slightly different because of a difference in interest rate calculation. McDonald and Thornton calculate the monthly interest rate as $0.06 / 12=0.005$. We calculate the monthly interest as $1.06(1 / 12)-1=0.004868$. This explains why our payments are slightly lower.
}

$\$ 33,344.41$ of the original $\$ 200,000$ loan. The month after the halfway point in the mortgage occurs at period 181. The interest payment component of the monthly payment still exceeds the principal payment. In payment period 219-18 years and 3 months into the contract-the principal component of the monthly payment finally exceeds the interest payment component. From this point forward, the principal payment will be larger than the interest payment. At the end of 20 years, or period 240, the principal component of the $\$ 1,178.74$ monthly payment is $\$ 655.01$. However, $\$ 106,941.84$ is still owed on the original $\$ 200,000$ loan. The outstanding loan balance does not drop below $\$ 100,000$ until payment period 251. With a standard 30-year mortgage contract, it takes nearly 22 years to pay off half the mortgage loan. The remaining half of the mortgage will be repaid in the final 8 years of this mortgage.

Example 2. Table 3 shows the standard 30year mortgage contract if the mortgage interest rate increases from 6 percent to 7 percent. A 1 percent increase in the interest rate increases the monthly mortgage payment from $\$ 1,178.74$ to $\$ 1,301.85-a$ a $\$ 23.11$ increase. Furthermore, the increase in the interest rate results in additional back-loading of principal payments. After 10 years, less than $\$ 30,000$ of the original balance is paid off. The payment period when the prin- 
Table 3

Characteristics of a Fixed-Rate Mortgage at 7 Percent*

\begin{tabular}{lcccc} 
Payment & Total payment (\$) & Interest (\$) & Principal (\$) & $\begin{array}{c}\text { Remaining } \\
\text { principal (\$) }\end{array}$ \\
\hline 1 & $1,301.85$ & $1,130.83$ & 171.02 & $199,828.98$ \\
2 & $1,301.85$ & $1,129.86$ & 171.99 & $199,656.99$ \\
120 & $1,301.85$ & 967.32 & 334.53 & $170,746.58$ \\
181 & $1,301.85$ & 830.00 & 471.85 & $146,322.72$ \\
239 & $1,301.85$ & 647.47 & 654.38 & $113,858.74$ \\
240 & $1,301.85$ & 643.77 & 658.08 & $113,200.66$ \\
260 & $1,301.85$ & 565.22 & 736.63 & $99,965.68$ \\
360 & $1,301.85$ & 7.31 & $1,294.54$ & 0.00 \\
Total & $468,666.00$ & $268,666.00$ & & - \\
NOTE: * Based on 30-year maturity. & & & & \\
\hline
\end{tabular}

cipal component exceeds the interest component does not occur until period 239. In fact, the outstanding balance will not drop below $\$ 100,000$ until payment $260-9$ months later than if the interest rate is 6 percent (as in Example 1).

This table clearly illustrates the impact of interest rate changes on a mortgage loan. If the total interest payments on the mortgage contract presented in Table 2 are compared with those in Table 3, the 1 percent increase in the interest rate results in $\$ 44,320$ of additional mortgage payments over the life of the mortgage.

\section{Mortgage with Constant Amortization}

As seen in Tables 2 and 3, the FRM accrues little equity in the initial years of the mortgage because most of the mortgage payment services interest payments. Some buyers would benefit by a combination of an FRM and faster equity accrual. Can a mortgage contract be designed to allow accrual of more equity in the initial periods, and what properties would be involved in such a contract? A mortgage contract with this benefit is known as a constant amortization mortgage (CAM). This loan contract allows constant contributions toward equity in each constant amortization mortgage period; that is, the amortization schedule is $A_{n}=A_{n+1}=A$. Because the interest repayment schedule depends on the size of outstanding level of debt, $D_{n}$, and the loan term, $N$, the mortgage payment, $m_{n}$, is no longer constant over the duration of the loan. Formally, the constant amortization term is calculated by

$$
A=\frac{D_{0}}{N}=\frac{(1-\chi) p h}{N} .
$$

If the expression for the interest payments is used, the monthly mortgage payment, $m_{n}$, will decrease over the length of the mortgage. This characteristic of the CAM follows from the decline in outstanding principal over the life of the contract. The monthly payment is determined by

$$
m_{n}=\frac{D_{0}}{N}+r^{m} D_{n} .
$$

For this contract, the changes in the outstanding level of debt and home equity are represented by

$$
D_{n+1}=D_{n}-\frac{D_{0}}{N}, \quad \forall n,
$$

and

$$
H_{n+1}=H_{n}+\frac{D_{0}}{N}, \quad \forall n .
$$

Example 3. We consider a $\$ 250,000$ 30-year loan with a 20 percent down payment and a 6 percent annual interest rate to show the charac- 


\section{Table 4}

\section{Characteristics of a Constant Amortization Mortgage at 6 Percent*}

\begin{tabular}{lcccc} 
Payment & Total payment (\$) & Interest (\$) & Principal (\$) & $\begin{array}{c}\text { Remaining } \\
\text { principal (\$) }\end{array}$ \\
\hline 1 & $1,529.07$ & 973.51 & 555.56 & $199,444.44$ \\
2 & $1,526.36$ & 970.81 & 555.56 & $198,888.89$ \\
120 & $1,207.27$ & 651.71 & 555.56 & $133,333.33$ \\
156 & $1,109.92$ & 554.36 & 555.56 & $113,333.33$ \\
181 & $1,042.31$ & 486.76 & 555.56 & $99,444.44$ \\
240 & 882.76 & 327.21 & 555.56 & $66,666.67$ \\
360 & 558.26 & 2.70 & 555.56 & 0.00 \\
Total & $375,718.58$ & $175,718.58$ & $200,000.00$ & -
\end{tabular}

NOTE: *Based on 30-year maturity.

teristics of this type of contract. Table 4 presents the monthly mortgage payment, principal component, and interest component.

The monthly payment with this contract has a much different profile than that of a fixed-payment mortgage loan. Clearly, the amount of the mortgage payment declines over the life of the loan. The initial payment is nearly three times the size of the payment in the last period. Principal payments are constant over the life of the loan, thus allowing for faster equity accumulation. Half of the original principal is repaid halfway through the loan. From a wealth accumulation perspective, this is an attractive feature. However, the declining payment profile is not positively correlated with a normal household's earning pattern during the first half of the life cycle: Mortgage payments are highest when earnings tend to be lower. From a household budget perspective, this could be a very unattractive option.

\section{Balloon and Interest-Only Loans}

The key property of the CAM is the payment of principal every period. In contrast, balloon and interest-only loans allow no amortization of principal throughout the term of the mortgage. A balloon loan is a very simple contract in which the entire principal borrowed is paid in full in the last payment period, $N$. This product tends to be more popular when mortgage rates are high and home buyers anticipate lower future mortgage rates. In addition, homeowners who expect to stay in their homes only for a short time may find this contract attractive as they are not concerned about paying principal. The amortization schedule for this contract can be written as

$$
A_{n}=\left\{\begin{array}{lr}
0 & \forall n<N \\
(1-\chi) p h & n=N
\end{array} .\right.
$$

This means that the mortgage payment in all periods, except the last period, is equal to the interest rate payment, $I_{n}=r^{m} D_{0}$. Hence, the mortgage payment for this contract can be specified as

$$
m_{n}=\left\{\begin{array}{ll}
I_{n} & \forall n<N \\
\left(1+r^{m}\right) D_{0} & n=N
\end{array},\right.
$$

where $D_{0}=(1-\chi) p h$. The evolution of the outstanding level of debt can be written as

$$
D_{n+1}=\left\{\begin{array}{ll}
D_{n}, & \forall n<N \\
0, & n=N
\end{array} .\right.
$$

With an interest-only loan and no change in house prices, the homeowner never accrues equity beyond the initial down payment. Hence, $A_{n}=0$ and $m_{n}=I_{n}=r^{m} D_{0}$ for all $n$. In essence, the homeowner effectively rents the property from the lender and the mortgage (interest) payments are the effective rental cost. As a result, the monthly 
Table 5

Characteristics of a Balloon Mortgage at 6 Percent*

\begin{tabular}{lcccc} 
Payment & Total payment (\$) & Interest (\$) & Principal (\$) & $\begin{array}{c}\text { Remaining } \\
\text { principal (\$) }\end{array}$ \\
\hline 1 & 973.51 & 973.51 & 0.00 & $200,000.00$ \\
2 & 973.51 & 973.51 & 0.00 & $200,000.00$ \\
180 & 973.51 & 973.51 & 0.00 & $200,000.00$ \\
181 & $1,670.59$ & 973.51 & 697.08 & $199,302.92$ \\
219 & $1,670.59$ & 832.25 & 838.34 & $170,141.84$ \\
240 & $1,670.59$ & 742.26 & 928.33 & $151,562.86$ \\
290 & $1,670.59$ & 487.16 & $1,183.43$ & $98,898.87$ \\
360 & $1,670.59$ & 8.09 & $1,662.50$ & 0.00 \\
Total & $475,938.02$ & $275,938.02$ & $200,000.00$ & -
\end{tabular}

NOTE: *Based on 30-year maturity, 15 years interest only.

\section{Table 6}

\section{Characteristics of an Adjustable-Rate Mortgage with a Constant Interest Rate of 6 Percent*}

\begin{tabular}{lcccc} 
Payment & Total payment (\$) & Interest (\$) & Principal (\$) & $\begin{array}{c}\text { Remaining } \\
\text { principal } \mathbf{( \$ )}\end{array}$ \\
\hline 1 & 973.51 & 973.51 & 0.00 & $200,000.00$ \\
2 & 973.51 & 973.51 & 0.00 & $200,000.00$ \\
36 & 973.51 & 973.51 & 0.00 & $200,000.00$ \\
37 & 1228.20 & 973.51 & 254.89 & $199,745.30$ \\
120 & $1,228.20$ & 847.10 & 381.10 & $173,648.03$ \\
181 & $1,228.20$ & 715.71 & 512.49 & $146,525.31$ \\
219 & $1,228.20$ & 611.86 & 616.34 & $125,086.37$ \\
240 & $1,228.20$ & 545.70 & 682.50 & $111,427.30$ \\
257 & $1,228.20$ & 486.97 & 741.23 & $99,303.08$ \\
360 & $1,228.20$ & 5.95 & $1,222.25$ & 0.00 \\
Total & $432,983.16$ & $232,983.16$ & $200,000.00$ & - \\
NOTE: *Based on 30-year maturity, 3 years interest only. & & &
\end{tabular}

mortgage payment is minimized because no periodic payments toward equity are made. A homeowner is fully leveraged with the bank with this type of mortgage contract. If capital gains are realized, the return on the housing investment is maximized. If the homeowner itemizes tax deductions, a large interest deduction is an attractive by-product of this contract.
Example 4. This example illustrates a balloon contract with a 15-year interest-only loan that is rolled into a 15-year fixed-payment mortgage. Table 5 shows the payment profiles for this contract. We also assume an interest rate of 6 percent and a 20 percent down payment.

The interest-only part of the loan requires 180 mortgage payments of $\$ 973.51$ just to cover 


\section{Table 7}

\section{Characteristics of an Adjustable-Rate Mortgage with a Rising Interest Rate*}

\begin{tabular}{lcccc} 
Payment & Total payment (\$) & Interest (\$) & Principal (\$) & $\begin{array}{c}\text { Remaining } \\
\text { principal (\$) }\end{array}$ \\
\hline 1 & 973.51 & 973.51 & 0.00 & $200,000.00$ \\
2 & 973.51 & 973.51 & 0.00 & $200,000.00$ \\
36 & 973.51 & 973.51 & 0.00 & $200,000.00$ \\
37 & $1,347.72$ & $1,130.83$ & 216.89 & $199,783.11$ \\
120 & $1,347.72$ & $1,001.40$ & 346.32 & $176,762.45$ \\
181 & $1,347.72$ & 859.24 & 488.48 & $151,477.91$ \\
239 & $1,347.72$ & 670.28 & 677.44 & $117,869.91$ \\
240 & $1,347.72$ & 666.45 & 681.27 & $117,188.65$ \\
264 & $1,347.72$ & 567.74 & 779.98 & $99,630.97$ \\
360 & $1,347.72$ & 7.57 & $1,340.15$ & 0.00 \\
Total & $471,707.64$ & $271,707.64$ & $200,000.00$ & -
\end{tabular}

NOTE: *Based on 30-year maturity, 3 years interest only at a 6 percent interest rate, and the remaining years at 7 percent.

the interest obligations on the $\$ 200,000$ loan. After 15 years, the mortgage payment increases to $\$ 1,670.59$ because the 15 -year balloon loan is rolled into a 15-year FRM. Payment number 219 denotes the month in which principal payments exceed interest payments. In period 290, half of the $\$ 200,000$ debt will be paid off. With this type of mortgage contract, it takes more than 24 years to accrue $\$ 100,000$ in equity.

Example 5. Some ARMs used in recent years have a very short period of interest-only payments. Table 6 presents the payment profiles for a 3-year interest-only ARM that rolls into a 27year standard FRM. The assumptions for the interest rate, total contract length, and down payment remain unchanged.

The monthly interest payments for this interest-only ARM are \$973.51. Once the standard 27-year contract takes effect, the monthly mortgage payment increases by $\$ 254.69$ to $\$ 1,228.20$. This increase is not caused by an interest rate increase, but rather payment toward principal.

Example 6. Mortgage interest rates have begun to increase recently. What effect does this have on an interest-only ARM? To show this effect, we allow the interest rate to increase to 7 percent for the standard FRM that is obtained after the 3-year ARM expires. Table 7 presents the various payment patterns. A 100-basis-point increase in the interest rate causes the monthly payment to increase to $\$ 1,347.72$ from $\$ 1,228.20$ a 38 percent increase in the mortgage payment from the interest-only payments. This example illustrates the risk facing homeowners when the interest rate increases before the transition to a standard FRM.

\section{Graduated-Payment Mortgages}

The repayment structures of the previous contract examples are relatively rigid. Payments are either constant during the entire contract or proportional to the outstanding level of debt. Mortgage contracts can be designed with a variable repayment schedule. This section focuses on mortgage loan payments that increase over time, $m_{1}<\ldots<m_{N}$. This feature could attract first-time buyers because payments are initially lower than payments in a standard contract. When a buyer's income grows over the life cycle, this loan product allows for stable housing expenditure as a ratio to income. However, the buyer's equity in the home builds at a slower rate than with the standard contract, which may explain this product's lack of popularity historically. Mortgage contracts with 
Table 8

Characteristics of a Graduated-Payment Mortgage: 1 Percent Geometric Growth Rate*

\begin{tabular}{lccrc} 
Payment & Total payment (\$) & Interest (\$) & Principal (\$) & $\begin{array}{c}\text { Remaining } \\
\text { principal (\$) }\end{array}$ \\
\hline 1 & 195.18 & 973.51 & -778.33 & $200,778.33$ \\
2 & 197.13 & 977.30 & -780.17 & $201,558.50$ \\
120 & 637.79 & $1,459.98$ & -822.19 & $300,763.84$ \\
181 & $1,170.26$ & $1,666.83$ & -496.57 & $342,933.91$ \\
220 & $1,725.11$ & $1,719.49$ & 5.57 & $353,260.70$ \\
240 & $2,104.96$ & $1,701.52$ & 403.44 & $349,161.20$ \\
344 & $5,924.70$ & 508.34 & $5,416.36$ & $99,017.59$ \\
360 & $6,947.18$ & 33.65 & $6,913.53$ & 0.00 \\
Total & $682,149.10$ & $482,149.10$ & $200,000.00$ & -
\end{tabular}

NOTE: *Based on interest rate of 6 percent, 30-year maturity, and a payment growth of 1 percent.

variable repayment schedules are known as graduated-payment mortgages (GPMs). These contracts are of special interest because their features are similar to those of mortgage contracts sold to subprime borrowers.

The repayment schedule for a GPM depends on the growth rate of these payments. The growth rate of payments is specified in the mortgage contract, and borrowers considering this contract must know this condition. We present examples to illustrate why knowledge of this parameter or condition is important. Typical GPM growth patterns are either geometric or arithmetic. We focus on GPMs with geometric growth patterns.

With this type of contract, mortgage payments evolve according to a constant geometric growth rate denoted by

$$
m_{n+1}=(1+g) m_{n}
$$

where $g>0$. This means the amortization and interest payments also increase as

$$
m_{n}=A_{n}+I_{n} .
$$

The initial mortgage payment is determined by

$$
m_{0}=\lambda_{g} D_{0}
$$

where $\lambda_{g}=\left(r^{m}-g\right)\left[1-\left(1+r^{m}\right)^{-N}\right]^{-1}$. The law of motion for the outstanding debt satisfies

$$
D_{n+1}=\left(1+r^{m}\right) D_{n}-(1+g)^{n} m_{0},
$$

and the amortization term is $A_{n}=\lambda_{g} D_{0}-r^{m} D_{n}$.

Example 7. Table 8 shows the implications for payments of a GPM contract when the mortgage payments grow at 1 percent per payment.

We maintain the assumption of a 30-year contract with a 20 percent down payment and a 6 percent annual interest rate.

Clearly, the initial payments of this mortgage are very low, which explains why this contract is attractive for first-time buyers. However, these low payments come at a cost: The monthly payment does not cover the interest on the outstanding balance. Thus, the remaining principal increases. This mortgage contract exhibits negative amortization. In this example, the mortgage payment does not cover the interest on the principal for the first 219 months. The maximum remaining principal for this home purchase increases to more than $\$ 350,000$ from the original $\$ 200,000$ debt. It is interesting to note that the final $\$ 100,000$ principal is paid in the final 16 months of this mortgage. Because the principal is back-loaded and must be paid off, the monthly payment must increase over time. The monthly mortgage payment tops out in the last month of the contract at $\$ 6,913.53$. A homeowner who chooses this con- 


\section{Table 9}

Characteristics of a Graduated-Payment Mortgage: 0.1 Percent Geometric Growth Rate*

\begin{tabular}{lcccr} 
Payment & Total payment (\$) & Interest (\$) & Principal (\$) & $\begin{array}{c}\text { Remaining } \\
\text { principal (\$) }\end{array}$ \\
\hline 1 & $1,030.68$ & 973.51 & 57.17 & $199,942.83$ \\
2 & $1,031.71$ & 973.23 & 58.48 & $199,884.36$ \\
120 & $1,160.85$ & 884.19 & 276.67 & $181,372.92$ \\
240 & $1,308.78$ & 614.19 & 694.59 & $125,485.59$ \\
273 & $1,352.67$ & 489.90 & 862.77 & $99,782.99$ \\
360 & $1,475.56$ & 7.15 & $1,468.41$ & 0.00 \\
Total & $446,356.77$ & $246,356.77$ & $200,000.00$ & -
\end{tabular}

NOTE: *Based on interest rate of 6 percent, 30 -year maturity, and a payment growth of 0.1 percent.

tract pays $\$ 482,149.10$ in total interest payments. Compared with the FRM contract presented in Table 2, total interest payments are more than double. These characteristics make GPMs risky from a lender's perspective because the potential for default is greater, which is one reason this type of contract has not historically been a factor in the mortgage market.

Example 8. Table 9 shows the importance of the payment growth parameter by reducing the monthly growth rate from 1 percent to 0.1 percent. Negative amortization does not occur with a lower monthly growth rate. Perhaps the most striking result is the amount of total interest payments over the length of the mortgage contract. When the mortgage contract has a 1 percent monthly growth rate, total interest payments are $\$ 482,149.10$. If the monthly growth rate falls to 0.1 percent, total interest payments are $\$ 246,356.77$. Clearly there is a cost to loans with negative amortization.

\section{Combo Loans}

In the late 1990s a new mortgage product became popular as a way to avoid large down payments and mortgage insurance. ${ }^{7}$ This product is known as the combo loan and amounts to two

7 Government-sponsored enterprises (GSEs) initiated the use of this product in the late 1990s and it became popular in private mortgage markets between 2001 and 2002 . different loans. Different types of CLs are offered in the mortgage industry; for example, an 80-15-5 loan implies a primary loan for 80 percent of the value, a secondary loan for 15 percent, and a 5 percent down payment. Another example is the so-called no-down-payment, or an 80-20 loan, which consists of a primary loan with a loan-tovalue ratio of 80 percent and a second loan for the 20 percent down payment.

Formally, the primary loan covers a fraction of the total purchase, $D_{1}=(1-\chi) p h$, with a payment schedule, $m_{n}^{1}$, and maturity, $N_{1}$. The second loan partially or fully covers the down payment, $D_{2}=\vartheta \chi p h$, where $\vartheta \in(0,1]$ and represents the fraction of the down payment financed by the second loan. The second loan has an interest premium $r_{2}^{m}=r_{1}^{m}+\zeta$ (where $\zeta>0$ ), a mortgage payment $m_{n}^{2}$, and a maturity $N_{2} \leq N_{1}$. In this case,

$$
m_{n}=\left\{\begin{array}{l}
m^{1}+m^{2} \text { when } N_{2} \leq n \leq N_{1} \\
m^{1} \text { when } n<N_{2}
\end{array} .\right.
$$

Because both loans are of a fixed-rate form, the laws of motion are equivalent to those presented in the FRM contract discussion. Table 10 shows characteristics of a CL.

Example 9. Table 10 presents the profile for an 80-20 CL for our $\$ 250,000$ house. The first $\$ 200,000$ is borrowed with the standard fixedpayment mortgage at 6 percent interest. The remaining $\$ 50,000$ is financed using another 
Table 10

Characteristics of an 80-20 Combo Loan Mortgage*

\begin{tabular}{lcccc} 
Payment & Total payment (\$) & Interest (\$) & Principal (\$) & $\begin{array}{c}\text { Remaining } \\
\text { principal (\$) }\end{array}$ \\
\hline 1 & $1,535.94$ & $1,295.21$ & 240.73 & $249,759.27$ \\
2 & $1,535.94$ & $1,293.98$ & 241.96 & $249,517.32$ \\
120 & $1,535.94$ & $1,094.04$ & 441.90 & $210,261.45$ \\
181 & $1,535.94$ & 931.49 & 604.45 & $178,528.13$ \\
156 & $1,535.94$ & 554.36 & 555.56 & $113,333.33$ \\
228 & $1,535.94$ & 765.78 & 770.16 & $146,301.19$ \\
240 & $1,535.94$ & 716.53 & 819.41 & $136,742.23$ \\
281 & $1,535.94$ & 522.76 & $1,013.15$ & $99,220.31$ \\
360 & $1,535.94$ & 7.99 & $1,527.95$ & 0.00 \\
Total & $552,938.40$ & $302,938.40$ & $250,000.00$ & -
\end{tabular}

NOTE: *Based on interest rate of 6 percent, 30-year maturity, and second loan rate of 8 percent.

fixed-payment mortgage that incorporates a risk premium of 2 percent. We will assume the second mortgage is also for 30 years. (In reality, the second mortgage is usually for 10 or 15 years.) The second loan for $\$ 50,000$ increases the monthly payment by $\$ 357.20$. The mortgage payment pattern of this CL is very similar to the basic fixedpayment mortgage. This is not surprising because the CL is nothing more than a combination of two FRMs. An obvious question for borrowers is why they should not obtain just one FRM with no down payment. The larger single loan would require mortgage insurance. The total monthly payment, including the mortgage insurance, would exceed the monthly payment on the CL. The CL is attractive for one segment of buyers who desire to enter the housing market: young buyers with high incomes. These buyers can afford the mortgage payment, but they have not yet had time to accumulate savings for the down payment.

\section{A MODEL OF HOUSING DECISIONS AND MORTGAGE CHOICES}

The previous section described various features and properties of mortgage contracts avail- able in the marketplace. However, the discussion did not detail the characteristics of individuals who might choose a particular contract. In addition, no mention was made of the ramifications of alternative contracts for the performance of the aggregate economy. The only way to discuss these issues is by analyzing alternative mortgages in the context of a model economy in which buyers can choose from among a set of mortgage products. In this section, we use a simplified version of the consumer problem used by Chambers, Garriga, and Schlagenhauf (2007a,b) to address the implications of mortgage choice for the performance of the aggregate economy (i.e., house prices, interest rates). This model allows us to focus on how types of mortgages influence the homeownership decision. This modeling style allows quick analysis of aggregate implications of mortgage markets and yet maintains the details needed to identify implications across different income, wealth distribution, and age cohorts.

\section{Model Features}

Age Structure. We develop a life cycle model with ex ante heterogeneous individuals. Let $j$ denote the age of an individual and let $J$ represent the maximum number of periods an individual 
can live. At every period, an individual faces mortality risk and uninsurable labor-earning uncertainty. The survival probability, conditional on the individual being alive at age $j$, is denoted by $\psi_{j+1} \in[0,1]$, with $\psi_{1}=1$ and $\psi_{j+1}=0$. Earning uncertainty implies that the individual is subject to income shocks that cannot be insured via private contracts. In addition, we assume that annuity markets for mortality risk are absent. The lack of these insurance markets creates a demand for precautionary savings to minimize fluctuations in consumption goods, $C$, and in the consumption of housing services, $s$, over the life cycle.

Preferences. Individual preferences rank goods (consumption and housing) according to a utility function, $u(c, s)$. The utility function has the property that additional consumption increases utility and also results in declining marginal utility. Consumption over periods is discounted at rate $\beta$ and, thus, lifetime utility is defined as

$$
v_{1}=E \sum_{j=1}^{J} \psi_{j} \beta^{j-1} u\left(c_{j}, s_{j}\right) .
$$

The assumption that utility is separable over time allows for a simple recursive structure of preferences for every realization of uncertainty:

$$
v_{1}=u\left(c_{1}, s_{1}\right)+\beta E \sum_{j=2}^{J} \psi_{j} \beta^{j-2} u\left(c_{j}, s_{j}\right) .
$$

Using the definition of expected lifetime utility, we can write the previous expression as

$$
v_{1}=u\left(c_{1}, s_{1}\right)+\beta E v_{2},
$$

where

$$
v_{2}=\sum_{j=2}^{J} \psi_{j} \beta^{j-2} u\left(c_{j}, s_{j}\right)
$$

represents the future lifetime expected utility.

Asset Structure. Individuals have access to a portfolio of assets to mitigate income and mortality risk. We consider two distinct assets: a riskless financial asset denoted by $a^{\prime}$ with a net return $r$ and a risky housing durable good denoted by $h^{\prime}$ with a market price, $p$, where the prime is used to denote future variables. To keep things simple, we assume that the price of housing does not change over time, so $p=p^{\prime}$. This assumption simplifies the problem because households do not need to anticipate changes in house prices. A housing investment of size $h^{\prime}$ can be thought of as the number of square feet in the house. A house of size $h^{\prime}$ yields $s$ services. ${ }^{8}$ If a household does not invest in housing, $h=0$, the household is a renter and must purchase housing services from a rental market. The rental price of a unit of housing services is $R$.

Housing investment is financed through longterm mortgage contracts and is subject to transaction costs. We need to summarize the information required so that the monthly payment, remaining principal, and equity position in the house can be identified for any mortgage contract. This critical information consists of the house size, $h$, the type of mortgage contract, $z$, and the remaining length of the mortgage, $n$. This information set can be used to identify the desired information concerning a household's mortgage contract.

Household Income. Household income varies over the buyer's life cycle and depends on whether the individual is a worker or a retiree. For workers younger than the mandatory retirement age, $j<j^{*}$, income is stochastic and depends on the basic wage income, $w$, a life cycle term that depends on age, $v_{j}$, and the persistent idiosyncratic component, $\varepsilon$, drawn from a probability distribution that evolves according to the transition law, $\Pi_{\varepsilon, \varepsilon^{\prime}}$. For an individual older than $j^{\star}$, a retirement benefit, $\theta$, is received from the government equal to $\theta$. Income can be specified as

$$
y\left(a, \varepsilon, j, v_{j}\right)= \begin{cases}w \varepsilon v_{j}+(1+r) a, & \text { if } j<j^{*}, \\ \theta+(1+r) a, & \text { if } j \geq j^{*}\end{cases}
$$

In the presence of mortality risk and missing annuity markets, we assume borrowing constraints, $a^{\prime} \geq 0$, to prevent individuals (buyers and renters) from dying with negative wealth. We also assume that households are born with initial wealth dependent on their initial income level.

The Decision Problem. Individuals make decisions about consumption goods, $c$, housing services, $s$, a mortgage contract type, $z$, and

8 For the sake of simplicity, we assume a linear relationship between house size and services generated. In other words, $s=h^{\prime}$. 


$$
\begin{aligned}
& \text { Current renter : } h=0 \quad\left[\begin{array}{l}
\text { Continues renting: } h^{\prime}=0 \\
\text { Purchases a house: } h^{\prime}>0
\end{array}\right. \\
& \text { Current owner : } h>0 \quad\left[\begin{array}{l}
\text { Stays in house: } h^{\prime}=h \\
\text { Changes size (upsize or downsize): } h^{\prime} \neq h \\
\text { Sell and rent: } h^{\prime}=0
\end{array}\right.
\end{aligned}
$$

investment in assets, $a^{\prime}$, and housing, $h^{\prime}$. The individual's current-period budget constraint depends on the household's asset holdings, the current housing investment, the remaining length of the mortgage, labor income shock, and age. We can isolate five possible decision problems that a household must solve.

The household value function, $v$, is described by a vector of so-called state variables that provide sufficient information of the position of the individual at the start of the period. The state vector is characterized by the level of assets at the start of the period, $a$, the prior-period housing position, $h$, the number of periods remaining on an existing mortgage, $n$, the mortgage contract type, $z$, the value of the current-period idiosyncratic shock, $\varepsilon$, and the age of the individual, $j$. To shorten notation of the individual's characteristics, we define $x=(a, h, n, z, \varepsilon, j)$. Using a recursive approach, we know that the household decisions for $c, s, z, a^{\prime}$ and $h^{\prime}$ depend on the $x$ vector. For example, suppose that $x$ contains the following information, $x=(1000,2000,56, F R M, 2,36)$. This vector tells us that the individual has $\$ 1,000$ of nonhousing wealth, a 2,000-square-foot home with a market value given by $p \times 2,000$, where $p$ represents the given price per square foot, 56 pending mortgage payments with the bank, an FRM, the income shock this period is two times average income, and the individual's age is 36 . The decisions made by this individual will differ from those of an individual who has a different state vector $x=(20000,2000,56, F R M, 2,41)$, because the second individual has more wealth and is 5 years older. For individuals who do not own a home, the information vector would have many zero entries, such as $x=(a, 0,0,0, \varepsilon, j)$.
Given all the possible options, the individual could be in one of five situations with respect to the housing investment and mortgage choice decisions. These five decisions are summarized in the box above.

We now detail the various decision problems. First, we consider an individual who starts as a renter and then consider an individual who starts as a homeowner.

Renters. An individual who is currently renting $(h=0)$ has two options: continue renting $\left(h^{\prime}=0\right)$ or purchase a house $\left(h^{\prime}>0\right)$. This is a discrete choice in ownership that can easily be captured by the value function, $v$ (present and future utility), associated with these two options. Given the relevant information vector $x=(a, 0,0$, $0, \varepsilon, j)$, the individual chooses the option with the higher value, which can be expressed as

$$
v(x)=\max \left\{v^{r}, v^{o}\right\} .
$$

The value associated with continued renting is determined by the choice of consumption goods, $c$, housing services, $s$, and investment in assets, $a^{\prime}$, which solves the problem

$$
\begin{aligned}
& V^{r}(x)=\max u(c, s)+\beta_{j+1} E V\left(x^{\prime}\right), \\
& \text { s.t. } c+a^{\prime}+R s=y(x) .
\end{aligned}
$$

The decisions are restricted to positive values for $c, s, a^{\prime}$ and the evolution of the state vector that summarizes the future information as given by $x^{\prime}=\left(a^{\prime}, 0,0,0, \varepsilon^{\prime}, j+1\right)$, where $a^{\prime}$ denotes next period's wealth, $\varepsilon^{\prime}$ represents next period's realization of the income shock, and $j+1$ captures the fact that the individual will be one period older.

The renter who chooses to purchase a house must solve a different problem as choices must now be made over $h^{\prime}>0$, a mortgage type, $z$, as 
well as $c, s$, and $a^{\prime}$. This decision problem can be written as

$$
\begin{aligned}
& V^{o}(x)=\max u(c, s)+\beta_{j+1} E v\left(x^{\prime}\right), \\
& \text { s.t. } c+a^{\prime}+\left[\varphi_{b}+\chi\left(z^{\prime}\right)\right] p h^{\prime}+m(x)=y(x) .
\end{aligned}
$$

It should be noted that a purchase of a house requires two up-front expenditures: transaction costs (i.e., realtors' fees, closing costs) that are proportional to the value of the house, $\varphi_{b} p h^{\prime}$, and a down payment to the mortgage bank for a fraction of the value of the house, $\chi\left(z^{\prime}\right)$ (i.e., 20 percent of the purchase price). These payments are incurred only at the time of the purchase. Homeowners also must make mortgage payments. These payments are denoted by $m(x)$ and depend on relevant variables, such as the loan amount, $(1-\chi) p h^{\prime}$, the type of mortgage (i.e., FRM vs. ARM), the length of the contract (i.e., 30 or 15 years), and the interest rate associated with the loan. It is important to restate that a homeowner who purchases a house of size $h^{\prime}$ receives $s$ units of housing consumption. The value of these housing services is denoted by $R s^{h}$. This value does not appear in the budget constraint because these services are consumed internally. As a result, the value of services generated is canceled by the value of services consumed internally. The household's decisions influence the information state in the following period; that is, $x^{\prime}=\left(a^{\prime}, h^{\prime}, N(z)-1, z^{\prime}, \varepsilon^{\prime}, j+1\right)$. Again, to determine whether an individual continues to rent or purchases a home, we need to solve both problems $-v^{r}(x)$ and $v^{0}(x)$ - and find the one that yields the highest value. When $v^{r}(x)>v^{0}(x)$, the individual continues to rent; otherwise he or she will become a homeowner.

Owners. The decision problem for an individual who currently owns a house, $(h>0)$, has a similar structure. However, a homeowner faces a different set of options: stay in the same house, $\left(h^{\prime}=h\right)$, purchase a different house, $\left(h^{\prime} \neq h\right)$, or sell the house and acquire housing services through the rental market, $\left(h^{\prime}=0\right)$. Given the relevant information $x=(a, h, n, z, \varepsilon, j)$, the individual solves

$$
v(x)=\max \left\{v^{s}, v^{C}, v^{r}\right\} .
$$

Each of these three different values is calculated by solving three different decision problems. If the homeowner decides to stay in the current house, the optimization problem can be written as

$$
\begin{aligned}
V^{s}(x) & =\max u\left(c, h^{\prime}\right)+\beta_{j+1} E v\left(x^{\prime}\right) \\
\text { s.t. } c+a^{\prime} & =y(x)-m(x) .
\end{aligned}
$$

This problem is very simple, because the homeowner must make decisions only on consumption and saving after making the mortgage payment. If the schedule of pending mortgage payments shows zero, $n=0$, then the implied mortgage payment is also set to zero, $m(x)=0$. The future state of information for this case is given by $x^{\prime}=\left(a^{\prime}, h^{\prime}, n^{\prime}, z^{\prime}, \varepsilon^{\prime}, j+1\right)$, where $n^{\prime}=\max \{n-1,0\}$.

For the homeowner who decides to either upsize or downsize, $\left(h \neq h^{\prime}\right)$, the problem becomes

$$
\begin{aligned}
& V^{c}(x)=\max u\left(c, h^{\prime}\right)+\beta_{j+1} E v\left(x^{\prime}\right) \\
& \text { s.t. } c+a^{\prime}+\left[\varphi_{b}+\chi\left(z^{\prime}\right)\right] p h^{\prime}+m(x) \\
& =y(x)+\left[\left(1-\varphi_{s}\right) p h-D(n, z)\right] .
\end{aligned}
$$

This individual must sell the existing property to purchase a new one. The choices depend on the income received from selling the property, $p h$, net of transactions costs from selling, $\varphi_{s}$, and the remaining principal, $D(n, z)$, owed to the lender. The standing balance depends on whether the mortgage has been paid off ( $n=0$ and $D(n, z)=0$ ) or not $(n>0$ and $D(n, z)>0$ ) and the type of loan contract. For example, mortgage loans with a slow amortization usually imply large remaining principal when the property is sold over the length of the loan, whereas contracts such as the constant amortization imply a much faster repayment. A new loan, $z^{\prime}$, must be acquired if the individual upsizes and purchases a new house, $h^{\prime}>0$. The relevant future information is given by $x^{\prime}=\left(a^{\prime}, h^{\prime}, N-1, z^{\prime}, \varepsilon^{\prime}, j+1\right)$.

Finally, we solve the problem of a homeowner who sells the house, $h>0$, and becomes a renter, $h^{\prime}=0 .{ }^{9}$ The optimization problem is very similar to the previous one. However, in this case the individual must sell the home and rent, Rs. Formally,

9 In the last period, all households must sell $h$, rent housing services, and consume all their assets, $a$, as a bequest motive which is not in the model. In the last period, $h^{\prime}=a^{\prime}=0$. 


$$
\begin{aligned}
& v^{r}(x)=\max u(c, s)+\beta_{j+1} E v\left(x^{\prime}\right), \\
& \text { s.t. } c+a^{\prime}+R s=y(x)+\left[\left(1-\varphi_{s}\right) p h-D(n, z)\right],
\end{aligned}
$$

where the relevant future information is simply given by $x^{\prime}=\left(a^{\prime}, 0,0,0, \varepsilon^{\prime}, j+1\right)$.

Given the initial information summarized in $x$, the choice of whether to stay in the house, change the housing size, or sell the house and become a renter depends on the values of $v^{s}, v^{c}$, and $v^{r}$.

\section{Aggregation and Parameterization}

We want our model economy to be consistent with certain features of the U.S. economy. In particular, we want to ensure that the choices of functional forms and parameter values are consistent with key features of the U.S. housing market. Replicating these features requires aggregating the microeconomic behavior of all the households in the economy. Because individuals are heterogeneous along six different dimensions-level of wealth, housing holdings, pending mortgage payments, type of mortgage used to finance the house, income shock, and age-our aggregation needs to take into account the number of individuals who have the same characteristics and the sum across these characteristics. To aggregate these dimensions, we define $\Phi(x)$ as the fraction of individuals who have a given level of characteristics $x=(a, h, n, z, \mathcal{\varepsilon}, j)$.

We can calculate aggregate statistics of the economy by taking the weighted average of all the household-level decisions across characteristics. As an example we would generate the aggregate housing stock, wealth, and consumption of housing services (or square feet) by calculating

$$
\begin{aligned}
H & =\int h^{\prime}(x) \Phi(d x) \\
W & =\int a^{\prime}(x) \Phi(d x) ; \\
S & =\int s(x) \Phi(d x) .
\end{aligned}
$$

The model can generate other aggregates of interest in a similar manner. We start by discussing how the model is parameterized.

Demographics. A period in the model is taken to be three years. Individuals enter the labor force at age 20 (model period 1) and potentially live until age 86 (model period 23). Retirement is assumed to be mandatory at age 65 (model period 16). Individuals survive to the next period with probability $\psi_{j+1} \cdot{ }^{10}$ The size of the age-specific cohorts, $\mu_{j}$, needs to be specified. Because of our focus on steady-state equilibrium, these shares must be consistent with the stationary population distribution. As a result, these shares are determined from $\mu_{j}=\psi_{j} \mu_{j-1} /(1+\rho)$ for $j=1,2, \ldots, J$ and

$$
\sum_{j=1}^{J} \mu_{j}=1 \text {, }
$$

where $\rho$ denotes the population growth rate. Using the resident population as the measure of the population, the annual growth rate is set at 1.2 percent.

Functional Forms. The choice of preferences is based on empirical evidence. The first-order condition that determines the optimal amount of housing consumption is denoted by

$$
\frac{u_{s_{j}}}{u_{c_{j}}}=R,
$$

where at the optimum $s_{j}=h_{j}^{\prime}$. Jeske (2005) documents that the $h_{j} / c_{j}$ ratio is increasing by age $j$. He points out that standard homothetic preferences over consumption and housing services,

$$
u\left(c_{j}, s_{j}\right)=\left[\gamma C_{j}^{\sigma}+(1-\gamma) s_{j}^{\sigma}\right]^{\frac{1}{\sigma}},
$$

imply a constant ratio

$$
\frac{h_{j}}{c_{j}}=\left(\frac{(1-\gamma)}{\gamma R}\right)^{\frac{1}{1-\sigma}},
$$

because the parameters $\gamma$ and $\sigma$ and the rental price $R$ do not vary across age. Therefore, this preference specification is inconsistent with the empirical evidence over the life cycle. A preference structure consistent with the evidence is denoted by

$$
u(c, s)=\gamma \frac{c^{1-\sigma_{1}}}{1-\sigma_{1}}+(1-\gamma) \frac{s^{1-\sigma_{2}}}{1-\sigma_{2}},
$$

where the implied first-order condition is denoted by

\footnotetext{
10 These probabilities are set at survival rates observed in 1994, and the data are from the National Center for Health Statistics (U.S. Department of Health and Human Services, 1994).
} 


$$
\frac{h_{j}^{\sigma_{2}}}{C_{j}^{\sigma_{1}}}=\frac{(1-\gamma)}{\gamma R} .
$$

This expression represents a nonlinear relationship between $h_{j}$ and $c_{j}$ that varies by age, $j$. The coefficients, $\sigma_{1}$ and $\sigma_{2}$, determine the curvature of the utility function with respect to consumption and housing services. The relative ratio of $\sigma_{1}$ and $\sigma_{2}$ determines the growth rate of the housing-to-consumption ratio. A larger curvature in consumption relative to the curvature in housing services implies that the marginal utility of consumption exhibits relatively faster diminishing returns. When household income increases over the life cycle (or different idiosyncratic labor income shocks), a larger fraction of resources is allocated to housing services. We set $\sigma_{2}=1$ and $\sigma_{2}=3$ to match the observed average growth rate while the preference parameter $\gamma$ is estimated. The discount factor, $\beta$, is set at 0.976 , which is derived from Chambers, Garriga, and Schlagenhauf (2007a).

Endowments. Workers are assumed to have an inelastic labor supply, but the effective quality of their supplied labor depends on two components. One component is age specific, $v_{j}$, and is designed to capture the hump in life cycle earnings. We use U.S. Census Bureau (1994) data to construct this variable. The other component captures the stochastic component of earnings and is based on Storesletten, Telmer, and Yaron (2004). We discretize this income process into a five-state Markov chain using the methodology presented by Tauchen (1986). Our reported values reflect the three-year horizon used in the model. As a result, the efficiency values associated with each possible productivity value, $\varepsilon$, are

$$
\varepsilon \in \mathbf{E}=\{4.41,3.51,2.88,2.37,1.89\},
$$

and the transition matrix is

$$
\pi=\left[\begin{array}{lllll}
0.47 & 0.33 & 0.14 & 0.05 & 0.01 \\
0.29 & 0.33 & 0.23 & 0.11 & 0.03 \\
0.12 & 0.23 & 0.29 & 0.24 & 0.12 \\
0.03 & 0.11 & 0.23 & 0.33 & 0.29 \\
0.01 & 0.05 & 0.14 & 0.33 & 0.47
\end{array}\right] .
$$

Each household is born with an initial asset position. This assumption accounts for the fact that some of the youngest buyers who purchase housing have some wealth. Failure to allow for this initial asset distribution creates a bias against the purchase of homes in the earliest age cohorts. As a result, we use the asset distribution observed in Panel Study on Income Dynamics (Institute for Social Research, 1994) to match the initial distribution of wealth for the cohort of age 20 to 23 .

Each income state has assigned the corresponding level of assets to match the nonhousing wealthto-earnings ratio. We choose the basic level of earnings, $w$, as a scaler to match labor earnings over total earnings.

Housing. The housing market introduces a number of parameters. The purchase of a house requires a mortgage and down payment. In this paper, we focus on the 30-year FRM as the benchmark mortgage. As a result of the assumption that a period is three years, we set the mortgage length, $N$, to 10 periods. The down payment, $\chi$, is set to 20 percent (matching facts from the 2004 U.S. Department of Commerce American Housing Survey, AHS). Buying and selling property is subject to transaction costs. We assume that all these costs are paid by the buyer and set $\sigma_{s}=0$ and $\sigma_{b}=0.06$.

Because of the lumpy nature of the housing investment (i.e., movement from $H=0$ to $H>0$ ), the specification of the second point in the housing grid has important ramifications. This grid point, $\underline{h}$, determines the minimum house size and has implications for the timing of investments in housing, wealth portfolio decisions, and the homeownership rate. We determine the size of this grid point as part of the estimation problem to avoid inadvertent implications on the results caused by this variable.

\section{Estimation}

We estimate five parameters using an exactly identified method of moments approach. The parameters that need to be estimated are the interest rate, $r$, the rental rate for housing, $R$, the price of housing, $p$, the wage rate $w$, and the size of the smallest housing investment position, $\underline{h}$. We identify these parameter values so that the 


\section{Table 11}

\section{Method of Moments Estimates*}

\begin{tabular}{|c|c|c|c|}
\hline Statistic & Data & Model estimate & Percent error \\
\hline 1. Ratio of wealth to gross domestic product & 2.541 & 2.549 & 0.314 \\
\hline 2. Ratio of housing stock to fixed capital stock & 0.430 & 0.4298 & -0.047 \\
\hline 3. Ratio housing services to consumption of goods & 0.230 & 0.235 & 2.7 \\
\hline 4. Labor earnings over total earnings & 0.700 & 0.71 & 1.4 \\
\hline 5. Homeownership rate & 0.640 & 0.643 & 0.468 \\
\hline Parameter & Value & & \\
\hline 1. Interest rate, $r$ & 0.0546 & & \\
\hline 2. Rental price, $R$ & 0.3403 & & \\
\hline 3. Housing price, $p$ & 1.4950 & & \\
\hline 4. Wage rate, $w$ & 0.8768 & & \\
\hline 5. Minimum house size, $\underline{h}$ & 1.4480 & & \\
\hline
\end{tabular}

resulting aggregate statistics in the model economy are equal to five targets observed in the U.S. economy.

i. Wealth-to-gross income ratio $(W / I)$. We find the target is the ratio of nonhousing wealth to gross income, which is about 2.541 (annualized value), for the period 1958-2001.

ii. Housing stock-to-wealth ratio $(H / W)$. For this ratio, the housing capital stock is defined as the value of fixed assets in owner and tenant residential property. The housing stock data are from the fixed asset tables of the Bureau of Economic Analysis (1958-2001) The ratio of the housing stock to nonhousing wealth is 0.43 .

iii. Housing services-to-consumption of goods ratio $(\boldsymbol{R S} / \boldsymbol{C})$. The targeted housing consumption-to-nonhousing consumption ratio is also based on National Income and Product Accounts (NIPA) data (1958-2001), where housing services are defined as personal consumption expenditure for housing while nonhousing consumption is defined as nondurable and services consumption expenditures net of hous- ing expenditures (U.S. Department of Commerce, NIPA tables). The targeted ratio for 1994 is 0.23 , but the number does not vary greatly over the period 1990-2000. This value is from Jeske (2005).

iv. Labor earnings over total earnings. The evidence from NIPA suggests that labor share of the economy is about 70 percent. We determine the value of $w$ to match this observation.

v. Homeownership ratio. This target is based on data from the AHS (1994) for 1994 and is equal to 64.0 percent.

Table 11 summarizes the parameter estimates and the empirical targets. The moments and the parameter values are presented in annual terms. The model nicely matches the moments of the U.S. economy.

\section{Model Evaluation}

We can now take a more in-depth look at the results from a distribution perspective. We begin by studying the homeownership rate across both the age and the income distribution (Table 12).

Another dimension of interest is the consumption of housing services. We measure average 


\section{Table 12}

\section{Homeownership Rates by Age}

\begin{tabular}{lcccccc} 
& \multicolumn{5}{c}{ Homeownership rate (percent) } \\
\cline { 2 - 7 } Variable & Total & 20-34 years & 35-49 years & 50-64 years & 65-74 years & 75-89 years \\
\hline Data 1994 & 64.0 & 40.0 & 64.5 & 75.2 & 79.3 & 77.4 \\
Baseline model 1994 & 64.3 & 37.1 & 80.6 & 81.5 & 81.5 & 62.5
\end{tabular}

SOURCE: U.S. Census Bureau, Housing Vacancies and Homeownership (1994) and U.S. Department of Commerce, American Housing Survey (1994).

Table 13

Owner-Occupied Housing Consumption by Age

\begin{tabular}{lcccccc} 
& \multicolumn{5}{c}{ House size (square footage) } \\
\cline { 2 - 7 } Simulation & Total & $\mathbf{2 0 - 3 4}$ years & $\mathbf{3 5 - 4 9}$ years & $\mathbf{5 0 - 6 4}$ years & $\mathbf{6 5 - 7 4}$ years & 75-89 years \\
\hline Data 1994 & 2,137 & 1,854 & 2,220 & 2,301 & 2,088 & 2,045 \\
Baseline model 1994 & 1,896 & 2,013 & 1,787 & 1,736 & 2,242 & 2,452
\end{tabular}

SOURCE: U.S. Department of Commerce, American Housing Survey (1994).

consumption of housing services by computing the average size of an owner-occupied house. Data from the AHS indicate the average owneroccupied house is 2,137 square feet. Our model implies an average house size of 1,895 square feet. Table 13 shows observed housing size by age cohorts. The model reasonably estimates homeowners' acquisition of appropriately sized homes. The average size for most age cohorts is within a few hundred square feet. Home size increases with age of the homeowner, which is observed only until age 65 in the data. ${ }^{11}$

Because households make savings decisions with respect to assets, the portfolio allocations implied by the model can be analyzed. In the model, a household's financial portfolio consists of asset holding and equity in housing investment. We use data from the 1994 Survey of Consumer Finances (Board of Governors, 1998) to determine the importance of housing in household portfolios.

\footnotetext{
${ }^{11}$ It should be noted that the full equilibrium model with landlords in Chambers, Garriga, and Schlagenhauf (2007a,b) does capture the hump-shaped pattern in home size.
}

We define assets as bond and stock holdings, and housing is defined as the estimated value of an existing homeowner's house adjusted for the remaining principal. The data indicate housing represents a large fraction of a household's portfolio in the youngest age cohorts. This fraction declines with household age until around retirement age and then increases as retirees consume their nonhousing wealth after retirement. As shown in Figure 1, our model generates a similar pattern.

\section{MORTGAGE CHOICES}

In this section we look at the implications of mortgage innovation on the housing market, especially with regard to the rate of homeownership. We focus on two of the largest mortgage innovations: ARM-type and CL mortgage contracts. In the first example, households face an additional decision regarding the type of mortgage to finance their home purchase. We will allow a potential home buyer to choose between a 30-year fixed- 


\section{Figure 1}

\section{Housing in the Portfolio by Age}

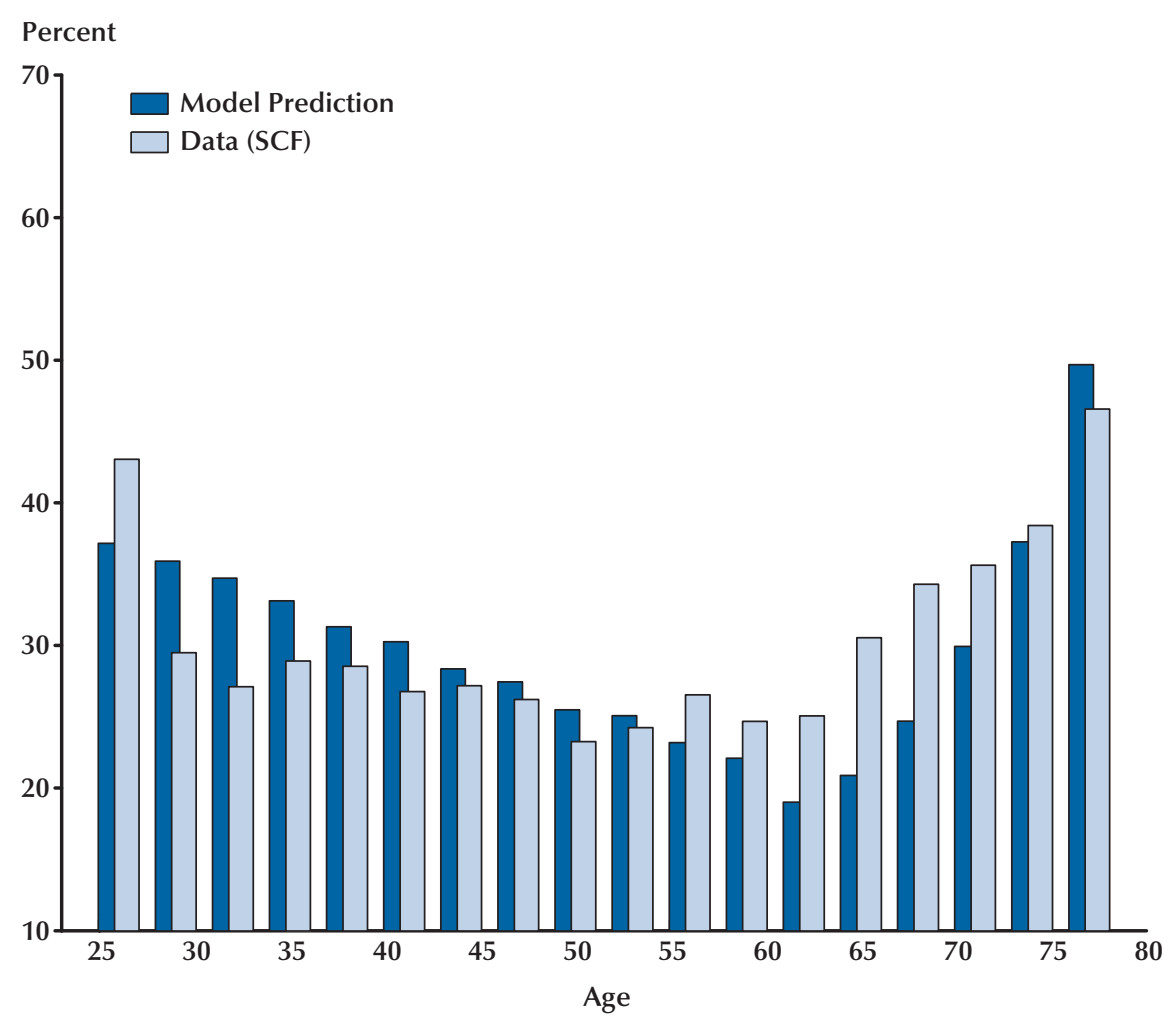

SOURCE: Survey of Consumer Finances (Board of Governors of the Federal Reserve System, 1998).

payment mortgage with a 20 percent down payment and an ARM with 3 years of interest-only payments followed by a 27-year fixed-payment mortgage. This simulation generates an aggregate homeownership rate of 65.83 percent, which is an increase of 1.5 percent from the baseline simulation. The effects are even more dramatic for homeownership rates by age.

Table 14 shows a very similar pattern to the baseline case with a few important differences. The biggest difference is the large increase in homeownership by the youngest cohort. For households younger than age 35, homeownership has surged to nearly 50 percent. Some of this increase in ownership is offset by a slight decrease in ownership later in life. This difference is explained by the labor income shocks for some of those who became owners by using ARM mortgages. The decision to own a home early in life delays the accumulation of capital assets, which insures the homeowner against bad income shocks. The average house size in this economy is 1,759 square feet. This implies that the introduction of ARMs leads to a large increase in the purchase of smaller homes, which tend to be purchased by lower-income households, who tend to be more exposed to labor income shocks. With out protection against income shocks, some homeowners are unable to make mortgage payments and thus become renters.

When considering mortgage finance and selection, we find that 51.7 percent of homeowners have some form of mortgage debt. As for the type of mortgage, 35.5 percent have a fixed-pay- 


\section{Table 14}

Homeownership (Including an ARM) by Age

\begin{tabular}{lcccccc} 
& \multicolumn{5}{c}{ Homeownership rate (percent) } \\
\cline { 2 - 7 } Simulation & Total & 20-34 years & 35-49 years & 50-64 years & 65-74 years & 75-89 years \\
\hline Benchmark & 64.3 & 37.1 & 80.6 & 75.2 & 79.3 & 77.4 \\
Model & 65.8 & 49.1 & 80.3 & 76.3 & 72.9 & 64.7
\end{tabular}

SOURCE: Data generated by the model.

Table 15

\section{Homeownership (Including Combo Loans) by Age}

\begin{tabular}{lcccccc} 
& \multicolumn{5}{c}{ Homeownership rate (percent) } \\
\cline { 2 - 7 } Simulation & Total & 20-34 years & 35-49 years & 50-64 years & 65-74 years & 75-89 years \\
\hline Benchmark model 1994 & 64.3 & 37.1 & 80.6 & 81.5 & 81.5 & 62.5 \\
Model & 68.6 & 42.2 & 88.0 & 81.6 & 83.2 & 66.9
\end{tabular}

SOURCE: Data generated by the model.

ment mortgage and 16.2 percent have an ARM mortgage. Only households with ARMs are in the bottom quintile of income distribution. ARMs can be attractive to many homeowners, but those who decide to become homeowners because of these loans are low-income households. Thus, mortgage contracts can influence asset decisions over the life cycle.

The next example considers the choice between a standard FRM and a CL when 80 percent of the home value is financed with a traditional fixed-payment mortgage and the other 20 percent is financed with another fixed-payment mortgage with a 2 percent interest rate premium. The aggregate homeownership rate in this economy is 68.65 percent. The introduction of a CL increases the homeownership rate by 4.3 percent. Table 15 shows how the homeownership rate decreases by age in this situation after the young est cohort period. Just as with an ARM, the homeownership rate of the youngest cohort increases from 37 to nearly 43 percent. However, because the payments of the typical CL combo loan are higher than a corresponding ARM, income con- straints prevent some young households from entering the market. Unlike the ARM, CL appears to have a positive effect across the entire age profile. Every age cohort has a homeownership rate at or above that in the baseline case.

The average home size in this economy is 1,909 square feet. This fact implies that the CL encourages the purchase of larger homes, which are affordable only for higher-income households. For this group, only 45.3 percent of the households have mortgage debt; 32.6 percent have a fixed-payment mortgage, and 12.7 percent have a CL. In addition, CLs are used in the bottom 40 percent of the income distribution. The income of an ARM household is lower than that of the average CL household.

\section{CONCLUSION}

This paper addresses several issues facing mortgage finance and potential home buyers. Recent innovations in the mortgage market have greatly expanded the types of loans available to home buyers. These products vary greatly in terms 
of payment size, composition of interest versus principal, and amortization schedule. Some products, such as interest-only loans, increase affordability by reducing payment size. However, these products typically slow accumulation of equity and thus become less attractive for wealth accumulation. Some mortgage types can generate negative amortization, which would seem highly unattractive to potential mortgage lenders. Other products, such as CLs, seek to increase affordability by reducing down payment requirements. These mortgages are characterized by larger mortgage payments. Given the typical government stance of seeking greater homeownership, both types of products appear successful in this regard.

In a standard macroeconomic model, we find that the typical ARM should generate large increases in the homeownership rate of young households. However, because of a delay in capital asset accumulation, lower homeownership may be found for older households. CLs also tend to drive up homeownership. For young households this increase in homeownership is not as pronounced as with ARMs, but with no apparent reduction in homeownership later in the life cycle. Thus, it should come as no surprise that the introduction of these mortgage products coincided with the observed increase in homeownership from 1995 through 2005. It should also not be surprising that the homeownership rate declines as these instruments are removed from the mortgage market.

\section{REFERENCES}

Chambers, Matthew; Garriga, Carlos and Schlagenhauf, Don. "Accounting for Changes in the Homeownership Rate.” International Economic Review, July 2007a (forthcoming).

Chambers, Matthew; Garriga, Carlos and Schlagenhauf, Don. "The Tax Treatment of Homeowners and Landlords," Working Paper, Florida State University, July 2007b.

Board of Governors of the Federal Reserve System. Survey of Consumer Finances, 1998; www.federalreserve.gov/pubs/oss/oss2/scfindex.html.
Institute for Social Research. Panel Study of Income Dynamics, 1994. Ann Arbor, MI: Institute for Social Research, University of Michigan; http://psidonline.irs.umich.edu/search.

Jeske, Karsten. "Macroeconomic Models with Heterogenous Agents and Housing." Federal Reserve Bank of Atlanta Economic Review, Fourth Quarter 2005, 90(4), pp. 39-56; www.frbatlanta.org/ filelegacydocs/erq405 jeske.pdf.

McDonald, Daniel J. and Thornton, Daniel L. "A Primer on the Mortgage Market and Mortgage Finance." Federal Reserve Bank of St. Louis Review, January/February 2008, 90(1), pp. 31-45; http://research.stlouisfed.org/publications/review/ 08/01/McDonald.pdf.

Storesletten, Kjetil, C.; Telmer, Chris I. and Yaron, Amir. "Consumption and Risk Sharing over the Life Cycle.” Journal of Monetary Economics, April 2004, 51(3), pp. 609-33.

The Mortgage Market Statistical Annual. Bethesda, MD: Inside Mortgage Finance Publications, 2007.

Tauchen, George. "Finite State Markov-Chain Approximation to Univariate and Vector Autoregressions.” Economic Letters, 1986, 20(2), pp. 177-81.

U.S. Bureau of Economic Analysis. National Income and Product Accounts; www.bea.gov/national.

U.S. Census Bureau. Housing Vacancies and Homeownership; www.census.gov/hhes/ www/housing/hvs/hvs.html.

U.S. Census Bureau. Residential Finance Survey: 2001-Census 2000 Special Reports (report CENSR-27); www.census.gov/prod/2005pubs/ census-27.pdf.

U.S. Census Bureau, U.S. Department of Commerce, Economics and Statistics Administration. Current Population Reports, Money Income of Households, Families, and Persons in the United States: 1994 (Series P60); www.census.gov/prod/www/abs/ income.html. 
U. S. Department of Commerce, Bureau of the Census. American Housing Survey, 2004 National File; www.census.gov/hhes/www/housing/ahs/ metropolitandata.html.

U.S. Department of Commerce, Bureau of Economic Analysis. National Income and Product Accounts; www.bea.gov/bea/dn/nipaweb/index.asp.
U.S. Department of Health and Human Services, Centers for Disease Control and Prevention, National Center for Health Statistics, Vital Statistics of the United States, 1994, Vol II, Mortality, Part A. section 6; www.cdc.gov/nchs/data/lifetables/ life94_2.pdf.

\section{APPENDIX}

Alm, James and J. Follain, James R., Jr. "Alternative Mortgage Instruments, the Tilt Problem and Consumer Welfare.” Journal of Financial and Quantitative Analysis, March 1984, 19(1), pp. 113-26.

Berkovec, James and Fullerton, Don. "A General Equilibrium Model of Housing, Taxes and Portfolio Choice.” Journal of Political Economy, April 1992, 100(2), pp. 390-429.

Campbell, John Y. “Household Finance,” Journal of Finance, August 2006, 61(4), 1553-604.

Campbell, John Y. and Cocco, Joao F. "Household Risk Management and Optimal Mortgage Choice.” Quarterly Journal of Economics, November 2003, 118(4), pp. 1449-94.

Chambers, Matthew; Garriga, Carlos and Schlagenhauf, Don. "The Loan Structure and Housing Tenure Decisions in an Equilibrium Model of Mortgage Choice.” Working Paper 2008-024A, July 2008, Federal Reserve Bank of St. Louis; http://research.stlouisfed.org/wp/2008/2008-024.pdf, July 2008, WP 2008-024A.

Cooley, Thomas F. and Prescott, Edward C. "Economic Growth and Business Cycles" in Thomas F. Cooley, ed., Frontiers of Business Cycle Research. Princeton, NJ: Princeton University Press, 1995, pp. 1-38.

Dhillon, Upinder S; Shilling, James D. and Simans, C.F. "Choosing Between Fixed and Adjustable Rate Mortgages.” Journal of Money, Credit and Banking, May 1987, 19(2), pp. 260-67.

Dunn, Kenneth B. and Spatt, Chester S. "An Analysis of Mortgage Contracting: Prepayment Penalties and the Due-on Sales Clause.” Journal of Finance, March 1985, 40(1), 293-308.

Fernández-Villaverde, Jesús and Krueger, Dirk. "Consumption and Savings over the Life-Cycle: How Important Are Consumer Durables?” Working Paper, University of Pennsylvania, December 19, 2005; www.econ.upenn.edu/ dkrueger/research/durables12192005sec.pdf.

Follain, James R. "Mortgage Choice." American Real Estate and Urban Economic Associations Journal, Summer 1990, 18(2), pp. 125-44.

Gouveia, Miguel and Strauss, Robert P. "Effective Federal Individual Income Tax Functions: An Exploratory Empirical Analysis.” National Tax Journal, June 1994, 47, pp. 317-39.

Gervais, Martin. "Housing Taxation and Capital Accumulation.” Journal of Monetary Economics, October 2002, 49(7), pp. 1461-89. 


\section{Chambers, Garriga, Schlagenhauf}

Heathcoate, Jonathan and Davis, Morris. "Housing and the Business Cycle." International Economic Review, August 2005, 46(3), pp. 751-84.

Henderson, J. Vernon and Ioannides, Yannis M. “A Model of Housing Tenure Choice.” American Economic Review, March 1983, 73(1), pp. 98-113.

Jeske, Karsten and Krueger, Dirk. "Housing and the Macroeconomy: The Role of Implicit Guarantees for Government-Sponsored Enterprises.” Federal Reserve Bank of Atlanta Working Paper 2005-15, August 2005; www.frbatlanta.org/filelegacydocs/wp0515.pdf.

Kearl, James R. "Inflation, Mortgages, and Housing.” Journal of Political Economy, October 1979, 87(5, Part 1), pp. 1115-38.

LeRoy, Stephen F. “Mortgage Valuation Under Optimal Repayment.” Review of Financial Studies, Autumn 1996, 9(3), pp. 817-44.

Li, Wenli. "Moving Up: Trends in Homeownership and Mortgage Indebtedness.” Federal Reserve Bank of Philadelphia Business Review, First Quarter 2005, pp. 26-34; www.philadelphiafed.org/files/br/brq105wl.pdf.

Li, Wenli and Yao, Rui. "The Life-Cycle Effects of House Price Changes.” Journal of Money, Credit and Banking, September 2007, 39(6), pp. 1375-409.

Nakajima, Makoto. "Rising Prices of Housing and Non-Housing Capital and Rising Earnings Instability: The Role of Illiquidity of Housing.” Working Paper, 2003, University of Pennsylvania.

Ortalo-Magne, François and Rady, Sven. "Housing Market Dynamics: On the Contribution of Income Shocks and Credit Constraints.” Review of Economic Studies, April 2006, 73(2), pp. 459-85.

Ríos-Rull, José-Victor. "Life Cycle Economies and Aggregate Fluctuations.” Review of Economic Studies, July 1996, 63(3), 465-89.

Ríos-Rull, José-Victor. "Population Changes and Capital Accumulation: The Aging of the Baby Boom.” The BE Journal of Macroeconomics, 2001, 1(1), article 7.

Ríos-Rull, José-Victor and Sanchez-Marcos, Virginia. “An Aggregate Economy with Different House Sizes.” Working Paper, September 2006, University of Pennsylvania; www.econ.umn.edu/ vr0j/papers/houaug06.pdf.

Sánchez, José Miguel. “An Estimable Dynamic Model of Housing Tenure Choice.” Unpublished manuscript, 2007, Instituto de Economía, Pontificia Universidad Católica de Chile.

Stanton, Richard and Wallace, Nancy. “Mortgage Choice: What's the Point?” Real Estate Economics, June 1998, 26(2), pp. 73-205. 